\title{
PBLBA as The Habituation Of Academic Cultures in The Student's Learning Environment
}

\author{
M Suswandari ${ }^{1,2}$, Siswandari $^{3}$, Sunardi $^{4}$, and Gunarhadi ${ }^{5}$ \\ $\left\{{ }^{1}\right.$ meidawatisuswandari@student.uns.ac.id $\}$ \\ 1,3,4,5 Sebelas Maret University, Indonesia \\ ${ }^{2}$ Universitas Veteran Bangun Nusantara, Indonesia
}

\begin{abstract}
The objective of this study was to describe Problem Based Learning Model Based on Academic Culture (PBLBA) as the spirit of learning as the academic culture for the students in the class. The research method was the literature study by collecting a number of books, papers, journals, leaflets and magazines that deal with the problems of the Problem Based Learning model based on academic cultures by Geert Hofstede. The data were collected by identifying books, papers or articles obtained. The data analysis used descriptive analysis, content analysis and critical analysis. The results of the study describe that the Problem Based Learning model whose syntax is modified with the basis of academic cultures from Geert Hofstede creates academic learning by habituating academic culture in each learning process. The habituation of academic cultures was realized by giving the students the problems to be studied together with their group friends without any awkwardness. Academic cultures also teach learning that is not teacher-centred. The main role of the students is to be actively invloved in classroom learning activities. The student is considered as someone who is able to have courage in arguing without coercion. There is no gap in terms of differences in sex of male or female students. Both have the same and fair role in the learning process in the classroom. The students have the role in the learning process with one to another responsibly.
\end{abstract}

Keywords: Problem Based Learning, Academic Culture

\section{INTRODUCTION}

Efforts to create an effective and conducive learning environment and to improve social skills require the interesting selection and packaging of learning models. Students are no longer burdened by teaching materials that must be mastered, but they learn by searching, processing and concluding the problems being studied. The selection of the right learning model will also clarify the concepts provided so that the students are always enthusiastic about thinking and playing an active role.

There are several learning models that enhance the students' learning activeness. One of them is the learning model that focuses on solving everyday problems, namely the Problem Based Learning model(PBL). PBL is a learning model that encourages students to learn and work together in groups to find solutions to problems in the real world. The examples of problems in life are used to activate the students' curiosity before starting to study a material. Problem Based Learning learning model is more effective than conventional methods. The effectiveness of this model is that the students are more active in thinking and understanding 
the material in groups by conducting investigations and inquiry on the real problems around them so that they get a deep and more meaningful impression of what they are learning.

According to Kelly and Finlayson, Problem Based Learning (PBL) was first introduced in 1969 at the medical faculty of McMaster University in Canada, and then developed in three other medical faculties of the University of Limburg in the Netherlands, University of Newcastle in Australia, and the University of New Mexico in the United States (Major, Mulvihill, Major, Mulvihill, \& State, 2018).Learning using the Problem Based Learning (PBL) model is learning by giving problems first before the students find a concept. Understanding of concepts can be developed through problem solving, reasoning and argumentation (NCTM, 2000).

The Problem Based Learning Model is a learning strategy in the scientific approach of the 2013 curriculum. The scientific approach was first introduced in the world of education in America in the late $19^{\text {th }}$ century, emphasizing formalistic laboratory methods that lead to scientific facts(Hodson, 1996). This approach has the characteristics of "doing science".This approach makes it easy for teachers or curriculum developers to improve the learning process by solving problems through more detailed steps and providing instructions for the students in carrying out learning activities. Scientific approach is the learning designed for the students to actively build concepts, laws or principles through the stages of observing, (to identify or find problems), formulating problems, proposing or formulating hypotheses, collecting data with various techniques, analysing data, drawing conclusions, and communicating concepts, laws or processes found(Hirshfield \& Koretsky, 2018).

Through the Problem Based Learning model in the scientific approach, it is also expected to improve the students' social skills. The Problem Based Learning model is the learning that does not separate academic skills from social skills, especially in relation to the ability to build productive social relationships. The desired achievement target is not only to facilitate the students to achieve good cognitive learning outcomes but also to train their ability to build teamwork and productive socio-cultural relations.

\section{RESEARCH METHOD}

The research method was the literature study by collecting a number of books, papers, journals, leaflets and magazines relating to the problem of learning models in students. The data were collected by identifying books, papers or articles obtained. The data analysis used descriptive analysis, content analysis and critical analysis. Descriptive analysis is collecting and compiling data based on library sources which is then analysed. Content analysis is utilizing a set of procedures in drawing conclusions from several documents that have been obtained. Critical analysis is interpreting the text and responding based on the literature study.

\section{RESULTS AND DISCUSSION}

It was stated by several researchers that the Problem-Based Learning (PBL) model is learning by using a problem approach as a context for in-depth investigation of what the students need and what they must do to to figure it out. The students explore their own information through problems that exist in their environment to look for causes and solutions to the problems studied.

Problem-based learning is different from didactic teaching in students. The students are faced with a description of a new situation or event and required to define their learning needs and questions to be able to understand the situation or event. Problem Based Learning is an educational approach that challenges the students to work cooperatively in groups to find 
solutions to real-world problems and to develop the skills to become independent students. Instructions are more student-centred. Learning is active rather than passive. The teacher plays several roles, including as lecturers, facilitators and trainers. In addition, this approach allows the students to analyse and solve complex, real-world problems, work together in groups and communicate verbally and in writing (Ramsay, Ph, Sorrell, \& Ed, 2006), (Gürsul \& Keser, 2009),(Akçay, 2009),(Bouhuijs, 2011), (Huang \& Wang, 2012),(Mcdonald \& Ogden-barnes, 2013),(Cullen, Cullen, \& Jackson, 2018)and(Ulger, 2018).

Meanwhile, in the application of learning by applying the basis of academic cultures according to Geert Hoftede and previous researchers, cultural differences have the same strength at the level of individual analysis regardless of gender differences, the academic interaction of the teacher and students with individual awareness without coercion so as not to feel a separate distance between the teacher and the student (Finch, 2010) and(Podrug, Pavičić, \& Bratić, 2006).

The speciality of Hofsteede's academic cultural habituation above is that learning is not teacher-centred and the main role of the students is to be actively involved in classroom learning activities. This is because there is no gap in status in terms of science between the teacher and students. The student is considered as someone who is able to have the courage to argue or present in front of the class without coercion. Likewise between one student to another, there are no gender differences between male and female students who will play a role in learning activities in the aspects of individual and group assignments because the students have a great sense of responsibility for not being selfish and individualist but being more concerned with social interaction and togetherness among them.

Hofstede adalah seorang sosiolog yang pada tahun 1967 sampai 1973 telah berhasil melakukan penelitian dengan mengumpulkan data dari 50 negara yang berbeda dalam perusahaan swasta International Bussiness Machine (IBM). Penelitian ini mendapatkan jawaban kurang lebih dari 100.000 kuesioner. Mendefinisikan budaya sebagai berikut: "The collective programming of the mind that distinguishes the members of one group or category of people from another." (G. Hofstede, Hofstede, \& Minkov, 2010; Geert Hofstede, 2011). More clearly Hofstede gives an argument about academic culture in the classroom including:

\subsection{Power Distance}

Hofstede defines Power Distance as follows: "The power distance between a boss $B$ and a subordinate $S$ in a hierarchy is the difference between the extent to which $B$ can determine the behavior of $S$ and the extent to which $S$ can determine the behavior". The concept of Power Distance or distance of power is the extent to which members of an organization or institution that are in a position that is not strong enough to accept and expect power to be distributed unevenly. The cultural dimension that supports low power distance (Small Power Distance) expects and accepts power relations more consultatively or democratically. People relate to each other regardless of the position of their formalities. Subordinates feel more comfortable and demand the right to contribute to decision making. If it is associated with academic culture in the classroom, there is no distance between the teacher and the student / student or the student and the teacher.

\subsection{Uncertainty Avoidance}

The dimension of uncertainty avoidance is explained by Hofstedeas follows: "Uncertainty about the future is a basic fact of human life with which we try to cope throuhj the domains of technology, law, and religion. In organizationas these take the form of technology, rules, and 
rituals. Uncertainty avoidance should not be confused with risk avoidance". The meaning of uncertainty avoidance is a form of public tolerance for uncertainty and ambiguity. This illustrates the extent to which members of organizations or institutions try to overcome feelings of anxiety and reduce the uncertainty they face. This understanding explains that uncertainty avoidance does not mean risk aversion. People who have a high uncertainty avoidance culture tend to be more emotional. They try to minimize the occurrence of unknown or unusual circumstances. When there is a change they live it carefully, step by step by planning and implementing applicable laws and regulations.In contrast, the low uncertainty avoidance cultural dimension accepts and feels comfortable in unstructured or environmental situations that often change. They try to have some rules in their activities. People in this cultural dimension tend to be more pragmatic, they are far more tolerant of change.

\subsection{Individualism Vs Collectivism}

Hofstede describes the dimension of individualism as the opposite side of collectivism as follows: "It describes the relationship between the individual and the collectivity that prevails in a given society. It is reflected in the way people live together-for example, in nuclear famiies, or tribes - and it has many implications for values and behavior". It means that an individualistic society will come under pressure or stress put on personal problems, and demand individual rights. People are expected to defend themselves and their families. In addition, they are also expected to choose their own affiliation. In contrast, in collectivist communities, individuals act as group members for life. High cohesiveness is created within their groups (groups here do not refer to politics or the state). People have large families, which are used as protection for themselves so that their loyalty is not in doubt.

\subsection{Masculinitiy Vs Feminity}

Hofstede explains masculinity and feminity as follows: The dominant gender role patterns in the vast majority of both traditional and modern societies. I will use 'sex' when referring to biological functions and 'gender' when referring to social functions". Masculinity is related to the value of gender differences in society, or the distribution of emotional roles between different genders. The values of the masculine dimension consist of the value of competitiveness, firmness, materialism, ambition and power. The feminine dimension (feminimity) places more value on relationships and quality of life. In the masculine dimension, the differences between gender roles appear more dramatic and less flexible than the feminine dimensions that see men and women of equal value, emphasizing simplicity and caring.

Therefore, the learning process built by Academic-Based Problem Based Learning (PBLBA) is learning with the assessment of problems in students who habituate academic values in the academic culture. It is guided by Hofstede's academic culture in the learning process, namely: (1) Power Distance, there is no distance between the teacher and the students or the students and the teacher in the classroom learning process. (2) Uncertainty Avoidance, the students do not feel reluctant to think and dare to present in front of the class without coercion. The students will choose low risks to create a comfortable learning atmosphere in the class. (3) Individualism versus Collectivism, related to the integration of individuals into the main groups. If it is associated with the academic culture in the classroom, the students who have a low dependence on the teacher (individualist nature) have the good responsibility that arises in them. (4) Masculinity versus Femininity, related to the division of emotional roles between women and men, similar to recognize the equality in the classroom learning process without looking at the male or female gender point of view. 


\section{CONCLUSIONS}

The conclusion in this study about Problem Based Learning model Based on Academic Culture (PBLBA) is that learning by refering to real problems around the students is by habituating academic cultural values. The habituation of the academic culture is through four things, namely Power Distance, Uncertainty Avoidanceand Individualism versus Collectivism and Masculinity versus Femininity.This means that problem-based learning is more studentcentred. The student is considered as someone who is able to have courage in arguing without coercion. In the class, there is no difference in the sex of male or female students, where both have the same role and responsibility both individually and in groups.

\section{ACKNOWLEDGMENT}

The author expressed his gratitude to LPDP who has helped with this research fee.

\section{REFERENCES}

[1] Akçay, B. (2009). Problem-Based Learning in Science Education, 6(1), 26-36.

[2] Bouhuijs, P. A. J. (2011). Implementing Problem Based Learning: Why is it so hard? Aprendizaje basado en la solución de problemas : ¿ por qué es tan difícil ? Resumen. Revista de Docencia Universitaria, 9(1), 17-24. Retrieved from http://redu.net/redu/index.php/REDU/article/viewFile/190/164

[3] Cullen, T., Cullen, T., \& Jackson, C. D. (2018). Problem-Based Learning in the Life Science Classroom , K - 12 The Interdisciplinary Journal of Problem-based Learning book review Problem-Based Learning in the Life Science Classroom , K - 12, 12(1), 36.

[4] Finch, N. (2010). Towards an Understanding of Cultural Influence on the International Practice of Accounting. Journal of International Business and Cultural Studies, 2, 1-6. Retrieved from http://0-search.proquest.com.innopac.up.ac.za//docview/759646754

[5] Gürsul, F., \& Keser, H. (2009). The effects of online and face to face problem based learning environments in mathematics education on student's academic achievement. Procedia - Social and Behavioral Sciences, 1(1), 2817-2824. https://doi.org/10.1016/j.sbspro.2009.01.501

[6] Hirshfield, L., \& Koretsky, M. D. (2018). Gender and Participation in an Engineering Problem-Based Learning Environment The Interdisciplinary Journal of Problem-based Learning Special Issue On Competency Orientation in Problem-Based Learning Gender and Participation in an Engineering Problem-Base, 12(1).

[7] Hodson, D. (1996). Laboratory work as scientific method: three decades of confusion and distortion, (789921171). https://doi.org/10.1080/0022027980280201

[8] Hofstede, G. (2011). Dimensionalizing Cultures: The Hofstede Model in Context Dimensionalizing Cultures : The Hofstede Model in Context, 2, 1-26.

[9] Hofstede, G., Hofstede, G. J., \& Minkov, M. (2010). Cultures and Organizations Software Of The Mind (Rev. 3rd ed.). New York: McGraw-Hill. Cultures and Organizations. https://doi.org/10.1007/s11569-007-0005-8

[10] Huang, K., \& Wang, T.-P. (2012). Utilizing Problem-based Learning (PBL) in a University English Interpretation Class. The Journal of Human Resource and Adult Learning, 8(1), 7-15. Retrieved from http://www.hraljournal.com/Page/2 Tzu-Pu Wang.pdf 
[11] Major, T., Mulvihill, T. M., Major, T., Mulvihill, T. M., \& State, B. (2018). ProblemBased Learning Pedagogies in Teacher Education: The Case of Botswana The Interdisciplinary Journal of Problem-based Learning Special Issue On Competency Orientation in Problem-BasED Learning Problem-Based Learning Pedagogies in Teacher Education , 12(1).

[12] Mcdonald, S., \& Ogden-barnes, S. (2013). Problem-based service learning with a heart : Organizational and student expectations and experiences in a postgraduate not-for-profit workshop event.

[13] NCTM. (2000). Executive summary - Principals and standards for school mathematics, 1-6. https://doi.org/10.1111/j.1949-8594.2001.tb17957.x

[14] Podrug, N., Pavičić, J., \& Bratić, V. (2006). Cross-cultural comparison of Hofstede's dimensions and decision-making style within CEE context. Proceedings of the ICES 3rd International Conference - From Transition to Sustainable Development: The Path to European Integration., 1-16. https://doi.org/10.1016/j.jaci.2013.06.036

[15] Ramsay, J., Ph, D., Sorrell, E., \& Ed, D. (2006). Problem-Based Learning : A Novel Approach to Teaching Safety, Health and Environmental Courses Safety Sciences Program Department of Industrial Management, (1), 1-8.

[16] Ulger, K. (2018). The Effect of Problem-Based Learning on the Creative Thinking and Critical Thinking Disposition of Students in Visual Arts Education The Interdisciplinary Journal of Problem-based Learning Article The Effect of Problem-Based Learning on the Creative Think, 12(1), 3-6. 